\title{
PENERAPAN PENDIDIKAN KARAKTER MELALUI KEGIATAN KEDISIPLINAN SISWA
}

\author{
Septi Wahyu Utami \\ Universitas PGRI Semarang \\ E-mail: septiwahyu35@gmail.com
}

\begin{abstract}
Abstrak
Penelitian ini bertujuan untuk mendeskripsikan Bagaimana penerapan pendidikan karakter melalui kegiatan kedisiplinan pada siswa di SDN Gayamsari 01 Semarang. Metode penelitian yang digunakan adalah menggunakan penelitian kualitatif, dimana dalam penelitian kualitatif instrument utama adalah peneliti itu sendiri. Dalam penelitian ini teknik pengumpulan data yang digunakan meliputi wawancara, observasi, dokumentasi dan angket. Penelitian ini dilaksanakan di SDN Gayamsari 01 Semarang bulan Desember 2018 - Januari 2019. Dalam penelitian ini digunakan uji keabsahan datatriangulasi. Hasil penelitian menunjukkan bahwa penerapan pendidikan karakter melalui kegiatan kedisiplinan di SDN Gayamsari 01 Semarang telah cukup berjalan dengan baik, kegiatan ini dilakukan dengan adanya kegiatan kedisiplinan upacara setiap hari senin dan apel pagi selain hari senin, kemudian juga ada kegiatan berbaris di dalam kelas sebelum masuk kelas untuk memulai pembelajaran serta ada kegiatanmelalui mapel agama yaitu kotak amal untuk bersedekah dan sholat dhuhur berjamaah di mushola sekolah, semua kegiatan tersebut dilakukan oleh pihak sekolah melalui metode pembiasaan.
\end{abstract}

Kata Kunci: Pendidikan, Karakter, Kedisiplinan.

\begin{abstract}
This study aims to describe the feasibility of character education through disciplinary activities in students at Gayamsari 01 Elementary School Semarang. The research method used is qualitative research, in which the main qualitative instrument research is the researcher itself. In this study the data technique used was interviews, documentation and questionnaires. This research was conducted at Gayamsari 01 Elementary School in Semarang from December 2018 January 2019. In this study the validity data of triangulation data were used. The results showed that the implementation of character education through disciplinary activities at Gayamsari 01 Public Elementary School was quite well underway, this activity was carried out with disciplinary announcement activities every Monday and morning apples in addition to Monday, then there were also activities marching in the classroom before entering the class for start learning and there are activities through religious maps, namely charity boxes for charity and dhuhur prayers in congregation at the school mosque, all activities carried out by the school through habituation methods.
\end{abstract}

Keywords: Education, Character, Discipline.

\section{PENDAHULUAN}

Pendidikan memiliki peran yang sangat penting dalam membentuk kualitas suatu bangsa. Sistem pendidikan nasional diharapkan harus mampu menjamin peningkatan mutu dan efisiensi manajemen pendidikan untuk menghadapi tantangan sesuai dengan tuntutan perubahan kehidupan di era global sehingga perlu dilakukan pembaharuan pendidikan secara terencana, terarah, dan berkesinambungan. Pendidikan merupakan suatu faktor utama yang menentukan kualitas suatu bangsa. Pendidikan selalu menuntut adanya suatu perbaikan yang bersifat terus menerus. Oleh karena itu pembaharuan selalu dilakukan untuk meningkatkan kualitas pendidikan nasional.

Dalam Undang-Undang No. 20 Tahun 2003 pasal 1 ayat I tahun 2003 tentang sistem pendidikan nasional, dinyatakan "Pendidikan adalah usaha sadar dan terencana untuk mewujudkan suasana belajar dan proses belajar agar peserta didik secara aktif membangun potensi dirinya untuk memiliki kekuatan spiritual keagamaan, pengendalian diri, kepribadian, kecerdasan, akhlak mulia, serta keterampilan yang diperlukan dirinya, masyarakat, bangsa dan negara". Sementara itu, di dalam kebijakan nasional, antara lain ditegaskan bahwa pembangunan karakter bangsa merupakan kebutuhan asasi dalam proses berbangsa dan bernegara. Sejak awal kemerdekaan, bangsa indonesia sudah bertekad untuk menjadikan pembangunan karakter bangsa sebagai bahan penting dan tidak dapat dipisahkan dari pembangunan nasional. Lebih lanjut harus diingat bahwa secara eksplisit pendidikan karakter (watak) adalah amanat UndangUndang Nomor 20 Tahun 2003 tentang sistem pendidikan nasional yang pada pasal 3 menegaskan bahwa "Pendidikan nasional berfungsi mengembangkan kemampuan dan membentuk watak 
serta peradaban bangsa yang bermartabat dalam rangka mencerdaskan kehidupan bangsa, bertujuan untuk berkembangnya potensi peserta didik agar menjadi manusia yang beriman dan bertakwa kepada Tuhan Yang Maha Esa, berakhlak mulia, sehat, berilmu, cakap, kreatif, mandiri, dan menjadi warga negara yang demokratis serta bertanggung jawab."

Dalam dunia pendidikan saat ini banyak ditemukan berbagai permasalahan, salah satunya adalah permasalahan karakter para siswa yang diantaranya ditunjukkan dengan adanya bullying antar sesama siswa, dan maraknya kenakalan siswa, serta masalah kedisiplinan siswa yang begitu kurang baik, hal ini menandakan bahwa moral para siswa yang semakin memburuk. Moral para siswa sekarang ini mengalami penurunan yang sangat memprihatinkan, hal ini karena adanya arus globalisasi yang semakin hari semakin pesat. Dengan adanya arus globalisasi ini banyak sekali dampak buruk yang mengakibatkan moral para siswa generasi sekarang merosot drastis. Oleh karena itu pendidikan karakter ini sangat penting diterapkan dalam pendidikan di indonesia untuk mengatasi penurunan moral yang dialami para siwa di generasi sekarang ini. Seorang siswa tidak cukup hanya dibekali materi pembelajaran saja melainkan juga harus dibekali oleh pendidikan karakter yang baik, yang tentunya agar berguna bagi kehidupannya kelak untuk menjadi individu yang berkarakter baik. Pendidikan karakter sebaiknya diberikan seiring dengan perkembangan intelektualnya, hal ini berarti pendidikan karakter harus ditanamkan sejak dini yang pertama kali diberikan oleh keluarga.

Menurut Lickonadalam (Muslich, 2011:44) mendefinisikan bahwa pendidikan karakter sebagai upaya yang dirancang secara sengaja untuk memperbaiki karakter para siswa. Pendidikan karakter ini tidak hanya diperoleh dari lingkungan keluarga saja melainkan sekolah juga berhak dalam melaksanakan pendidikan karakter bagi siswa siswanya. Dengan adanya pendidikan karakter di sekolah maka akan dapat membantu pembentukkan kepribadian yang baik dalam diri siswa. Pendidikan di sekolah sangat diperlukan, walaupun dasar dari pendidikan karakter adalah di dalam keluarga. Kalau seorang anak mendapatkan pendidikan karakter yang baik dari keluarganya, anak tersebut akan berkarakter baik pada tahap selanjutnya. Namun banyak orang tua yang lebih mementingkan aspek kecerdasan otak ketimbang pendidikan karakter. Selain itu Daniel Goleman dalam (Muslich, 2011:30) mengatakan bahwa banyak orang tua yang gagal dalam mendidik karakter anak-anaknya baik karena kesibukan maupun karena lebih mementingkan aspek kognitif anak. Meskipun demikian, kondisi ini dapat ditanggulangi dengan memberikan pendidikan karakter di sekolah.

Pendidikan karakter sangat penting diterapkan. Hal ini sesuai dengan pendapat Lickona bahwa ada tujuh alasan mengapa pendidikan karakter itu harus disampaikan yaitu : (1) Cara terbaik untuk menjamin anak -anak (siswa) memiliki kepribadian yang baik dalam kehidupannya. (2) Cara untuk meningkatkan prestasi akademik. (3) Sebagian siswa tidak dapat membentuk karakter yang kuat bagi dirinya sendiri di tempat lain. (4) Mempersiapkan siswa untuk menghormati pihak lain atau orang lain dan dapat hidup dalam masyarakat yang beragam. (5) Berangkat dari akar masalah yang berkaitan dengan masalah moral - sosial, seperti ketidaksopanan, ketidakjujuran, kekerasan, pelanggaran kegiatan seksual, dan etos kerja (belajar) yang rendah. (6) Sebagai persiapan terbaik untuk menyongsong perilaku di tempat kerja. (7) Mengajarkan akan nilai-nilai budaya merupakan bagian dari kerja peradaban.

Berdasarkan pengamatan yang dilakukan penulis di SDN Gayamsari 01 Semarang. Bahwa di sekolah tersebut ada beberapa masalah pendidikan yang ada salah satunya yaitu permasalahan karakter para siswa, ada siswa yang nakal dan suka melakukan bullying sesama siswa di sekolah tersebut, kemudian juga masalah kedisiplinan siswa yang sangat kurang. Untuk mengatasi masalah ini diketahui bahwa di sekolah tersebut telah menerapkan pendidikan karakter di sekolah melalui kegiatan kedisiplinan, seperti contohnya pembiasaan disiplin melalui kegiatan upacara dan apel pagi, berbaris sebelum masuk kelas, ada juga pembiasaan jabat tangan kepada guru setiap pagi untuk menumbuhkan sikap sopan santun kepada sesama, dan masih banyak kegiatan lainnya, dengan adanya kegiatan ini diharapkan akan dapat membantu siswa dalam pembentukkan kepribadiannya menjadi lebih baik lagi terutama dalam hal kedisiplinan. Tujuan penelitianadalah Untuk mendeskripsikan Bagaimana penerapan pendidikan karakter melalui kegiatan kedisiplinan pada siswa di SDN Gayamsari 01 Semarang.

\section{METODE}

Dalam penelitian ini penulis menggunakan penelitian deskriptif dengan pendekatan kualitatif. Data dalam penelitian ini berupa data kualitatif, yaitu data dengan menggunakan kata-kata atau pendeskripsian mengenai fakta atau fenomena yang sedang diamati.Sumber Data dalam penelitian ini dapat berupa data primer. Data primer adalah yaitu sumber data yang langsung memberikan data kepada pengumpul data.

Dalam penelitian kualitatif, yang menjadi instrumen atau alat penelitian adalah peneliti itu sendiri, dengan sunyek penelitian adalah siswa kelas 3A SDN Gayamsari 01 Semarang. Prosedur pengumpulan data yang dilakukan dalam penelitian ini menggunakan beberapa cara agar data yang diperoleh merupakan data yang valid dan kredibel mengenai penelitian ini. Dalam penelitian ini teknik pengumpulan data yang digunakan meliputi wawancara, observasi, dokumentasi dan angket.Penelitian ini dilaksanakan di SDN Gayamsari 01 Semarang. SDN Gayamsari 01 semarang beralamat di Jl. Beruang Raya No. 01 Semarang 50161. 
Penelitian ini dilaksanakan antara bulan Desember 2018 - Januari 2019.Dalam penelitian ini digunakan uji keabsahan data uji credibility (validitas internal). Uji credibility antara lain dilakukan dengan perpanjangan pengamatan, peningkatan ketekunan dalam penelitian, triangulasi, diskusi dengan teman sejawat, analisis kasus negatif dan member check. Uji credibility yang digunakan adalah dengan menggunakan triangulasi.Metode analisis data yang digunakan dalam penelitian ini adalah metode analisis data selama di lapangan model Miles and Huberman. Analisis data dalam penelitian ini dilakukan pada saat pengumpulan data berlangsung, dan setelah selesai pengumpulan data dalam periode tertentu. Miles and Huberman (1984), mengemukakan bahwa aktivitas dalam analisis data kualitatif dilakukan secara interaktif dan berlangsung secara terus menerus sampai tuntas, sehingga datanya sudah jenuh. Aktivitas dalam analisis data, yaitu data reduction, data display, dan conclusion drawing/verification.

\section{HASIL DAN PEMBAHASAN}

Dengan penelitian yang telah dilakukan di SDN Gayamsari 01 Semarang Hasil dari penelitian ini menunjukkan bahwa penerapan pendidikan karakter melalui kegiatan kedisiplinan siswa di SDN Gayamsari 01 Semarang dilakukan dalam berbagai kegiatan. Kegiatan ini adalah adanya kegiatan upacara setiap hari senin dan apel pagi setiap hari selain hari senin, dengan adanya kegiatan ini diharapkan penerapan pendidikan karakter melalui kegiatan kedisiplinan dapat menjadikan memiliki karakter yang baik khususnya dalam karakter disiplin, karena anak sudah diajarkan sejak dini mengenai kedisiplinan yang harus dilakukan. Selain kegiatan upacara dan apel pagi ada juga kegiatan baris di depan kelas sebelum masuk ke dalam kelas ketika pembelajaran akan berlangsung, kegiatan ini akan menjadikan anak mempunyai disiplin yang baik dalam proses pembelajaran, selain itu ada juga kegiatan amal setiap ada mapel agama dala kelas tersebut sehingga dengan adanya kegiatan amal ini akan melatih anak dalam disiplin melakukan hal- hal baik untuk dirinya sendiri. Dengan adanya amal ini anak juga diajarkan bagaimana peduli pada sesama juga menjalankan perintah dari Tuhan untuk melakukan sedekah semampu kita. Selain kegiatan amal pada setiap ada mapel agama juga ada penanaman nilai-nilai karakter religius lainnya yaitu dengan adanya sholat dhuhur berjamah di mushola sekolah, dengan adanya kegiatan ini maka dapat melatih siswa dalam pembentukan disiplin untuk taat dalam beribadah. Semua penanaman penerapan pendidikan karakter melalui kedisiplinan di SD tersebut dengan menggunakan metode pembiasaan. Pembiasaan ini dilakukan oleh semua elemen yang ada di sekolah ersebut sehingga semua elemen berperan semua dalam pembentukan karakter yang baik melalui kegiatan disiplin di sekolah tersebut. Menurut Mulyasa (2011:166) Pembiasaan adalah sesuatu yang sengaja dilakukan secara berulang-ulang agar sesuatu itu dapat menjadi kebiasaan. Pembiasaan sebenarnya berintikan pengalaman, yang dibiasakan itu adalah sesuatu yang diamalkan. Pembiasaan menempatkan manusia sebagai sesuatu yang istimewa, yang dapat menghemat kekuatan, karena akan menjadi kebiasaan yang melekat, dan spontan, agar kekuatan itu dapat dipergunakan untuk berbagai kegiatan dalam setiap pekerjaan, dan aktivitas lainnya. Dalam bidang psikologi pendidikan, metode pembiasaan dikenal dengan istilah operan conditioning, mengajarkan peserta didik untuk membiasakan perilaku terpuji, disiplin, giat belajar, bekerja keras, ikhlas, jujur, dan bertanggung jawab atas setiap tugas yang telah diberikan.

Pendidikan melalui pembiasaan dapat dilaksanakan secara terpogram dalam pembelajaran, dan secara tidak terpogram dalam kegiatan sehari-hari. Kegiatan pembiasaan terpogram dalam pembelajaran dapat dilaksanakan dengan perencanaan khusus dalam kurun waktu tertentu untuk mengembangkan pribadi peserta didik secara individual, kelompok, dan atau klasikal. Kegiatan pembiasaan secara tidak terpogram dapat dilaksanakan secara

Rutin, yaitu pembiasaan yang dilakukan terjadwal, seperti: upacara bendera, senam, shalat berjamaah, keberaturan, pemeliharaan kebersihan dan kesehatan diri.

Spontan, yaitu pembiasaan tidak terjadwal dalam kejadian khusus seperti: pembentukan perilaku memberi salam, membuang sampah pada tempatnya, antre, mengatasi silang pendapat (pertengkaran).

Keteladanan, yaitu pembiasaan dalam bentuk perilaku sehari-hari seperti: berpakaian rapi, berbahasa yang baik, rajin membaca, memuji kebaikan dan keberhasilan orang lain, datang tepat waktu.

Dalam pelaksanaan pendidikan karakter di sekolah, pembiasaan peserta didik untuk berperilaku baik perlu ditunjang oleh keteladanan guru dan kepala sekolah, dan semua elemen dalam sekolah, di sekolah tersebut telah terlihat banyak semua elemen sekolah telah ikut serta dalam pionir untuk menerapkan pendidikan karakter di sekolah tersebut.

Penerapan pendidikan karakter di sekolah ini memang dilakukan dengan cara pembiasaan kedisiplinan dengan adanya hal ini diharapkan siswa akan memiliki karakter yang baik, terlihat penerapan pendidikan karakter ini sudah cukup berjalan dengan baik hal ini ditunjukan dengan karakter siswa yang sudah baik dalam hal kedisiplinannya yang sudah diterapkan melalui berbagai kegiatan walaupun masih ada beberapa siswa yang belum bisa memiliki karakter yang diharapkan melalui kegiatan-kegiatan yang telah dilaksanakan sekolah.

\section{PENUTUP \\ Simpulan}

Simpulan dalam penelitian ini adalah bahwa penerapan pendidikan karakter melalui kegiatan kedisiplinan di SDN Gayamsari 01 Semarang telah 
cukup berjalan dengan baik, kegiatan ini dilakukan dengan adanya kegiatan kedisiplinan upacara setiap hari senin dan apel pagi selain hari senin, kemudian juga ada kegiatan berbaris di dalam kelas sebelum masuk kelas untuk memulai pembelajaran serta ada kegiatan kedisiplinan melalui mapel agama yaitu kotak amal untuk bersedekah dan sholat dhuhur berjamaah di mushola sekolah, semua kegiatan tersebut dilakukan oleh pihak seklah melalui metode pembiasaan. Dengan adanya penerapan kegiatan ini terlihat kebanyakan siswa telah mempunyai karakter yang diharapkan dengan adanya kegiatan yang telah dilakukan walaupun masih ada beberapa siswa yang belum mempunyai karakter yang baik.

\section{Saran}

Berkaitan dengan penelitian yang telah dilakukan peneliti menyadari bahwa masih banyak kekurangan dalam melakukan penelitian. Untuk itu bagi peneliti yang ingin meneliti masalah penerapan karakter hasil penelitian ini dapat dijadikan sebagai referensi untuk menyempurnakan penelitian yang telah dilakukan. Dan untuk pihak sekolah dengan adanya penelitian ini maka pihak sekolah dapat memperbaiki dan mengembangkan lagi penanaman atau penerapan pendidikan karakter di sekolah.

\section{DAFTAR PUSTAKA}

Citra, Yulia. Pelaksanaan Pendidikan Karakter dalam Pembelajaran. 2012. Jurnal Ilmiah Pendidikan Khusus Volume 1 Nomor 1 Januari 2012.

Daryanto, S. D. 2013. Implementasi Pendidikan Karakter di Sekolah. Yogyakarta: Gava Media.

Goleman, Daniel. 2001. Kecerdasan Emosional untuk Mencapai Puncak Prestasi. Jakarta: PT Gramedia.

H. E. Mulyasa, M. 2011. MANAJEMEN PENDIDIKAN KARAKTER. Jakarta: Bumi Aksara.

Hendriana, Evinna Cinda \& Arnold Jacobus. 2016. Implementasi Pendidikan Karakter di Sekolah melalui Keteladanan dan Pembiasaan. Jurnal Dasar Pendidikan Dasar Indonesia Volume 1 Nomor 2 September 2016.

Lickona, Thomas. 2003. Character Matters: How to Help Our Children Develop Good Judgement, Integrity, and Other Essential Virtues. New York: Simon \& Schuster.

Muchlas Samani, D. H. 2011. Konsep dan Model Pendidikan Karakter. Bandung : PT Remaja Rosdakarya.
Miles, M.B. \& Huberman, A.M. 1984. Qualitative Data Analysis. London: Sage Publisher.

Muslich, M. 2011. PENDIDIKAN KARAKTER Menjawab Tantangan Krisis Multidimensional. Jakarta: PT Bumi Aksara.

Soegeng A. Y. Ysh., M. D. 2016. Landasan Pendidikan Karakter. Yogyakarta: Magnum Pustaka Utama.

Sugiyono, P. D. 2014. METODE PENELITIAN PENDIDIKAN Pendekatan Kuantitatif, Kualitatif, dan R\&D. Bandung: Alfabeta.

Undang-Undang Nomor 20 Tahun 2003 tentang Sistem Pendidikan Nasional Pasal 1 Ayat 1. 